\title{
Effects of varying rates of tallgrass prairie hay and wet corn gluten feed on productivity of lactating dairy cows
}

\author{
D. J. Rezac, ${ }^{*}$ K. N. Grigsby, $\dagger^{1}$ N. M. Bello, $\neq$ and B. J. Bradford ${ }^{\star 2}$ \\ ${ }^{*}$ Department of Animal Sciences and Industry, Kansas State University, Manhattan 66506 \\ †Cargill Incorporated, Blair, NE 68008 \\ ‡Department of Statistics, Kansas State University, Manhattan 66506
}

\begin{abstract}
Productivity of lactating dairy cows fed diets with wet corn gluten feed (WCGF, Sweet Bran, Cargill Inc., Blair, NE) as the primary energy substrate and prairie hay as the primary source of physically effective neutral detergent fiber (peNDF) was assessed relative to a control diet. Forty-eight Holstein cows, 100 to $250 \mathrm{~d}$ in milk, were randomly assigned to 1 of 6 pens and pens were randomly assigned to treatment sequence in a replicated $3 \times 3$ Latin square. Treatments were a control diet with $18 \%$ alfalfa, $18 \%$ corn silage, $33 \% \mathrm{WCGF}$, and $15 \%$ forage NDF (CON); a diet with $20 \%$ tallgrass prairie hay, 46\% WCGF, and 13\% forage NDF (TPH20); and a diet with $14 \%$ tallgrass prairie hay, $56 \%$ WCGF, and $9 \%$ forage NDF (TPH14). Midway through period 2, TPH14 was discontinued due to the high prevalence of diarrhea among cows on that treatment. Data from period 2 for TPH14 pens were discarded, and the pens that had been assigned to TPH14 for period 3 were randomly assigned to the other 2 treatments. Pen-level data were analyzed using linear mixed models, including the random effects of period and pen and the fixed effect of treatment. For animal-level data, additional random effects were introduced to account for subsampling. No evidence for treatment effects was apparent on dry matter intake. Least squares mean milk yields were $36.2,34.6$, and $35.2 \mathrm{~kg} / \mathrm{d}$ for CON, TPH20, and TPH14, respectively, and were not significantly different. Milk fat concentration was higher for CON and TPH20 than for TPH14, with means of 3.48, 3.41, and $2.82 \%$, respectively. Fat yield was significantly greater for CON compared with TPH20 and TPH14. Milk urea nitrogen was greatest for TPH20 and TPH14 and least for CON, consistent with differences in dietary protein content. Efficiencies, expressed as energy-corrected milk divided by dry matter intake, were 1.47, 1.42, and 1.24 for CON, TPH20, and TPH14, respectively, and were
\end{abstract}

Received July 20, 2011.

Accepted October 20, 2011.

${ }^{1}$ Current address: J. D. Heiskell \& Co., Amarillo, TX 79102.

${ }^{2}$ Corresponding author: bbradfor@ksu.edu not significantly different. These data indicate that TPH14 did not provide adequate peNDF to support normal rumen function in mid lactation dairy cows; instead, TPH20 may be a feasible diet for use on dairies where high-NDF grass hay and WCGF are available.

Key words: wet corn gluten feed, dairy cow, physically effective fiber

\section{INTRODUCTION}

Low milk prices or small profit margins lead dairy farmers to search for opportunities to reduce input costs. Often the first area of focus is feed cost, because this represents the largest cost for dairy producers, accounting for about $50 \%$ of the total operating and ownership costs for dairies in the US heartland (Short, 2004). Novel diet formulation methods using atypical feedstuffs or uncommon inclusion rates may be a way to decrease ration costs. Additionally, in circumstances in which supplies of typical feedstuffs may not be sufficient for a production year, a diet that includes alternative feed ingredients that are readily and locally available may help dairy producers to maintain acceptable productivity without the cost of purchasing forages from distant sources.

Wet corn gluten feed (WCGF), a co-product of the wet-milling process, is a high-fiber, low-lignin feedstuff that has been repeatedly demonstrated to be a viable option for inclusion into lactating dairy cattle rations (Wickersham et al., 2004; Mullins et al., 2009). Although the fiber in WCGF is highly digestible, its effective NDF content can be variable depending on the method used to estimate it. Allen and Grant (2000) calculated the effective NDF (eNDF) of WCGF to be 32.9 or $5.71 \%$ based on change in milk fat concentration and ruminal $\mathrm{pH}$, respectively, and physically effective NDF (peNDF) of WCGF to be $4.8 \%$, based solely on rumination activity. Regardless of which figure is used, peNDF must be supplied by other fiber sources to prevent ruminal acidosis or milk fat depression. However, WCGF is also quite low in rapidly fermentable carbohydrates (such as starch) compared with other high energy feedstuffs, so the risk of ruminal acidosis is 
decreased (Wickersham et al., 2004). Considering this, it may be possible to formulate a diet with a high inclusion rate of WCGF and lower peNDF.

Dietary sources of peNDF have traditionally been forages such as alfalfa or corn silage. In a survey conducted in the summer of 1995 by Mowrey and Spain (1999), $62 \%$ of the lactating dairy cattle across the United States were fed alfalfa hay and $61 \%$ were fed some type of corn forage. Tallgrass prairie hay (TPH), a mixture of many grass species native to the central plains region, is a relatively inexpensive forage fiber source that is typically fed to beef cattle or far-off dry dairy cows with low energy requirements. According to Olson et al. (2008), TPH contains an average of $67.4 \%$ NDF, $15.2 \%$ acetyl bromide lignin, and $3.9 \%$ CP. Thus, TPH may provide a low-cost, physically effective source of NDF in rations.

Taken together, the unique characteristics of TPH and WCGF may serve to complement each other in lactating dairy cow rations. However, no published research has shown the effects of such a diet compared with one containing common ingredients such as alfalfa hay and corn silage. Our objectives were to compare diets containing varying amounts of TPH and WCGF to a control diet and observe effects on productivity of lactating dairy cows.

\section{MATERIALS AND METHODS}

\section{Animals, Design, and Diets}

Twenty-one primiparous and 27 multiparous lactating Holstein cows $(167 \pm 47 \mathrm{DIM}, 1.8 \pm 0.97$ lactations, mean $\pm \mathrm{SD}$ ) were selected from the Kansas State University Dairy Teaching and Research Center herd and randomly assigned to 1 of 6 freestall pens. Experimental procedures were approved by the Institutional Animal Care and Use Committee at Kansas State University. Pens were assigned to treatment sequence in a replicated $3 \times 3$ Latin square design that was balanced for carryover effects of treatments. Treatment periods were $21 \mathrm{~d}$, with $17 \mathrm{~d}$ of diet adaptation and $4 \mathrm{~d}$ of sampling; feeding of treatments began in September and continued through November 2009. Cows were fed fresh TMR blended in a TMR wagon daily at $0930 \mathrm{~h}$ and milked 3 times daily at 0600, 1300, and $2000 \mathrm{~h}$.

Treatments were a diet containing $18 \%$ of DM alfalfa hay and $18 \%$ of DM corn silage (control, CON), a diet containing $20 \%$ of DM TPH (TPH20), and a diet containing $14 \%$ of DM TPH (TPH14; Table 1). Diets were formulated to be isocaloric and isonitrogenous, with varying amounts and sources of forage NDF; however, chemical analysis after the experiment showed that diets were not completely isonitrogenous. Water was added to TPH20 and TPH14 diets to target a DM concentration of $60 \%$, with the goal of limiting ration sorting.

Cows fed TPH14 during period 1 had loose stools, but no health problems were observed, and no animals were considered to have diarrhea. However, midway through period 2, feeding of TPH14 was discontinued due to visual observations of diarrhea in $>25 \%$ of cows consuming that diet, across both pens. The 2 pens on TPH14 were switched to the CON diet for the remainder of period 2 (data were not collected), and pens allocated to TPH14 in period 3 were instead assigned to either TPH20 or CON. The resulting treatment allocations are represented in Table 2. The statistical models fitted to the data (see later) recognize periods as incomplete blocks (i.e., all treatments were present in period 1 but TPH14 was missing in periods 2 and 3 ). Fitting period as a random effect using a mixed model approach effectively borrows information across periods to allow for inference on treatment effects for CON, TPH20, and TPH14. The smaller number of observations available for TPH14 translates into increased inferential uncertainty for this treatment, as demonstrated by the magnitude of the estimated standard errors of the least squares means estimates associated with TPH14, as well as the estimated standard errors of estimated pairwise treatment differences involving this treatment.

\section{Data and Sample Collection and Analysis}

Feed offered and refused for each pen was recorded on the final $4 \mathrm{~d}$ of each treatment period. Samples of the TMR were also gathered on these days and composited by period; particle size was analyzed using a 4-compartment Penn State Particle Separator (Kononoff et al., 2003). After separation, each fraction was dried for $48 \mathrm{~h}$ in a $55^{\circ} \mathrm{C}$ forced-air oven, and then weighed to determine particle size distribution on a DM basis. Physically effective NDF was calculated as the proportion of particles retained on the top 2 sieves multiplied by the NDF content of the diet $\left(\mathbf{p e N D F} \mathbf{8 . 0}_{\mathbf{0}}\right.$, Table 1; Yang and Beauchemin, 2009).

Samples of corn silage, alfalfa hay, TPH, WCGF, cottonseed, and grain mixes were gathered on d 18 and 21 of each period, composited, and then dried for $48 \mathrm{~h}$ in a $55^{\circ} \mathrm{C}$ forced-air oven before laboratory analysis. All samples were ground to pass through a 1-mm screen utilizing a Wiley mill (Arthur H. Thomas, Philadelphia, PA), and DM content was determined by drying at $105^{\circ} \mathrm{C}$ in a forced-air oven for $12 \mathrm{~h}$. Crude protein content was estimated by determination of elemental nitrogen content (Leco Analyzer, Leco Corp., St. Joseph, MI). Neutral detergent fiber concentration was quantified according to Van Soest et al. (1991; method 
REZAC ET AL.

Table 1. Ingredient and nutrient composition of experimental diets

\begin{tabular}{|c|c|c|c|}
\hline \multirow[b]{2}{*}{ Item } & \multicolumn{3}{|c|}{ Treatment $^{1}$} \\
\hline & $\mathrm{CON}$ & ТPH20 & TPH14 \\
\hline \multicolumn{4}{|l|}{ Ingredient, $\%$ of DM } \\
\hline Corn silage & 17.6 & - & - \\
\hline Alfalfa hay & 17.7 & - & - \\
\hline Tallgrass prairie hay & - & 19.2 & 13.8 \\
\hline $\mathrm{WCGF}^{2}$ & 33.0 & 46.1 & 56.0 \\
\hline Cottonseed & 7.3 & 7.5 & 7.5 \\
\hline Corn grain & 16.6 & 17.5 & 15.6 \\
\hline Soybean meal, $48 \% \mathrm{CP}$ & 1.0 & 2.6 & - \\
\hline Expeller soybean meal $^{3}$ & 4.1 & 4.2 & 4.2 \\
\hline Limestone & 1.2 & 1.6 & 1.7 \\
\hline Magnesium oxide & 0.1 & 0.1 & 0.1 \\
\hline Sodium bicarbonate & 0.8 & 0.8 & 0.8 \\
\hline Trace mineral salt & 0.5 & 0.1 & 0.1 \\
\hline Salt & 0.03 & - & - \\
\hline Micronutrient premix ${ }^{4}$ & 0.13 & 0.13 & 0.13 \\
\hline \multicolumn{4}{|l|}{ Nutrient, \% of DM } \\
\hline DM, $\%$ as fed & 62.7 & 60.7 & 61.5 \\
\hline $\mathrm{CP}$ & 16.5 & 18.0 & 18.6 \\
\hline $\mathrm{NE}_{\mathrm{L}},{ }^{5} \mathrm{Mcal} / \mathrm{kg}$ & 1.65 & 1.60 & 1.59 \\
\hline NDF & 34.5 & 38.3 & 37.0 \\
\hline Forage NDF & 15.3 & 12.9 & 9.3 \\
\hline Ether extract & 3.6 & 4.1 & 3.7 \\
\hline Starch & 20.8 & 13.9 & 12.1 \\
\hline $\mathrm{NFC}^{6}$ & 34.5 & 30.7 & 31.2 \\
\hline Ash & 10.9 & 8.9 & 9.5 \\
\hline \multicolumn{4}{|c|}{ Physically effective fiber, ${ }^{7} \%$ of DM } \\
\hline $\operatorname{peNDF}_{8.0}$ & $15.9 \pm 2.8$ & $11.8 \pm 2.5$ & $10.7 \pm 4.3$ \\
\hline peFNDF $_{8.0}$ & $7.3 \pm 0.9$ & $3.9 \pm 0.9$ & $1.1 \pm 1.1$ \\
\hline \multicolumn{4}{|c|}{${ }^{1} \mathrm{CON}=$ control, $\mathrm{TPH} 20=$ tallgrass prairie hay $20 \%, \mathrm{TPH} 14=$ tallgrass prairie hay $14 \%}$. \\
\hline \multicolumn{4}{|c|}{${ }^{2}$ Wet corn gluten feed (Sweet Bran, Cargill Inc., Blair, NE). } \\
\hline \multicolumn{4}{|c|}{${ }^{3}$ SoyBest (West Point, NE). } \\
\hline \multicolumn{4}{|c|}{$\begin{array}{l}{ }^{4} \text { Micronutrient premix consisted of } 30.2 \\
\text { MN), } 23.3 \% \text { vitamin E premix (44 IU/g } \\
(20,000 \mathrm{IU} / \mathrm{g}) \text {. }\end{array}$} \\
\hline \multicolumn{4}{|c|}{${ }^{5}$ Calculated according to NRC (2001). } \\
\hline \multicolumn{4}{|c|}{${ }^{6}$ Calculated as DM - (ash + ether extract + NDF + CP) } \\
\hline \multicolumn{4}{|c|}{$\begin{array}{l}{ }^{7} \text { peNDF }_{8.0} \text { (physically effective NDF) was calculated as the proportion of particles retained on the top } 2 \text { sieves } \\
\text { of a Penn State Particle Separator multiplied by the total dietary NDF concentration (Yang and Beauchemin, } \\
\text { 2009); peFNDF } \text {, }_{8.0} \text { (physically effective forage NDF) was calculated as the proportion of particles retained on } \\
\text { the top } 2 \text { sieves of a Penn State Particle Separator multiplied by the total dietary forage NDF concentration. }\end{array}$} \\
\hline
\end{tabular}

A) by using an Ankom Fiber Analyzer (Ankom Technology, Fairport, NY) with sodium sulfite and amylase. Crude fat was determined by ether extraction (AOAC, 2000; method 920.9). Ash content was measured following $8 \mathrm{~h}$ of incineration at $500^{\circ} \mathrm{C}$ by a muffle furnace. Results of nutrient analyses for key ingredients are shown in Table 3.

Milk samples were collected from each cow at every milking during the last $4 \mathrm{~d}$ of each period. Samples were composited over a 48-h period and analyzed for fat, true protein, and lactose with a B2000 Infrared Analyzer (Bentley Instruments, Chaska, MN), somatic cells were counted using a flow cytometer laser (Somacount 500; Bentley Instruments), and urea N was determined using chemical methodology based on a modified Berthelot reaction (ChemSpec 150 analyzer; Bentley
Instruments) at Heart of America DHIA (Manhattan, $\mathrm{KS}$ ). Body weight was measured on d 21 of each period immediately following the milking at $1300 \mathrm{~h}$.

Table 2. Treatments assigned to each pen throughout the study ${ }^{1}$

\begin{tabular}{llll}
\hline & \multicolumn{3}{c}{ Period } \\
\cline { 2 - 4 } Pen & 1 & 2 & 3 \\
\hline 1 & TPH20 & CON & TPH20 \\
2 & CON & Treatment ended & TPH20 \\
3 & TPH14 & TPH20 & CON \\
4 & CON & TPH20 & CON \\
5 & TPH20 & Treatment ended & CON \\
6 & TPH14 & CON & TPH20 \\
\hline${ }^{1}$ CON $=$ control, TPH20 = tallgrass prairie hay $20 \%$, TPH14 $=$ tall-
\end{tabular}
grass prairie hay $14 \%$. 
Table 3. Composition of corn silage, alfalfa hay, wet corn gluten feed (WCGF), and tallgrass prairie hay ${ }^{1}$

\begin{tabular}{lcrcr}
\hline & \multicolumn{3}{c}{ Ingredient } \\
\cline { 2 - 5 } Nutrient & \multicolumn{1}{c}{ Corn } & Alfalfa & \multicolumn{1}{c}{ Tallgrass } \\
silage & hay & WCGF & $88.5 \pm 4.1$ \\
\hline DM & $36.9 \pm 1.8$ & $89.5 \pm 1.7$ & $58.5 \pm 0.5$ & $67.5 \pm 5.3$ \\
NDF & $43.2 \pm 3.5$ & $43.6 \pm 1.4$ & $37.5 \pm 0.7$ & $6.6 \pm 0.9$ \\
CP & $8.0 \pm 0.8$ & $18.3 \pm 1.4$ & $22.9 \pm 0.5$ & $1.7 \pm 0.2$ \\
Ether extract & $2.9 \pm 0.8$ & $1.1 \pm 0.2$ & $2.6 \pm 0.5$ & $7.3 \pm 0.2$ \\
Ash & $5.2 \pm 0.6$ & $11.4 \pm 1.3$ & $5.8 \pm 0.1$ & \\
\hline
\end{tabular}

${ }^{1}$ All nutrients except DM are expressed as a percentage of diet DM. Values are means \pm SD, representing 1 sample analysis per period $(\mathrm{n}=3)$.

\section{Statistical Analysis}

During period 2, two cows were removed from the study due to health problems associated with TPH14. Two additional cows were removed from the study because of health issues unrelated to treatment. Dry matter intake was adjusted using the number of cows within each pen to account for inequality of animal numbers within pen. Milk yield and composition data were averaged across the 4-d collection period for each cow before statistical analysis. Data were analyzed using JMP (version 8.0, SAS Institute, Cary, NC) according to the following statistical models. The model for pen-level data was

$$
\mathrm{Y}_{\mathrm{ilk}}=\mu+\mathrm{T}_{\mathrm{i}}+\mathrm{P}_{\mathrm{j}}+\mathrm{N}_{\mathrm{k}}+\mathrm{e}_{\mathrm{ijk}}
$$

where $\mu$ is the overall mean, $T_{i}$ is the fixed effect of treatment ( $\mathrm{i}=1$ to 3 ), $\mathrm{P}_{\mathrm{j}}$ is the random effect of period ( $\mathrm{j}=1$ to 3 ), $\mathrm{N}_{\mathrm{k}}$ is the random effect of pen ( $\mathrm{k}=1$ to 6 ), and $e_{i j k}$ is the pen-level residual error. Pen-level data included DMI, feed efficiency, and particle size analyses.

The model for cow-level data was

$$
\mathrm{Y}_{\mathrm{ijkl}}=\mu+\mathrm{T}_{\mathrm{i}}+\mathrm{P}_{\mathrm{j}}+\mathrm{N}_{\mathrm{k}}+\mathrm{C}_{\mathrm{l}}\left(\mathrm{N}_{\mathrm{k}}\right)+\mathrm{TN}_{\mathrm{ik}}+\mathrm{e}_{\mathrm{ijkl}},
$$

where $\mu$ is the overall mean, $T_{i}$ is the fixed effect of treatment ( $\mathrm{i}=1$ to 3 ), $\mathrm{P}_{\mathrm{j}}$ is the random effect of period ( $\mathrm{j}=1$ to 3 ), $\mathrm{N}_{\mathrm{k}}$ is the random effect of pen ( $\mathrm{k}=1$ to 6 ), $\mathrm{C}_{\mathrm{l}}\left(\mathrm{N}_{\mathrm{k}}\right)$ is the random effect of cow $(\mathrm{l}=1$ to 8$)$ nested within pen, $\mathrm{TN}_{\mathrm{ik}}$ is the random effect of treatment-bypen combination intended to recognize pen as the experimental unit for treatment, and $\mathrm{e}_{\mathrm{ijk}}$ is the cow-level residual error. Cow-level data included milk and milk component yields, milk composition, and BW change. In this model, treatment by pen interaction was the error term for fixed effect tests, ensuring that pen served as the experimental unit.

For all variables, values with a Studentized residual $>|4|$ were determined to be outliers and were removed before final analysis; no more than $2.5 \%$ of values were designated as outliers for any analysis. Significant effects were declared at $P<0.05$.

\section{RESULTS AND DISCUSSION}

\section{Diet Composition and Particle Size}

Physically effective $\mathrm{NDF}_{8.0}$ values, calculated according to Yang and Beauchemin (2009), were 15.6, 11.8, and $10.7 \%$ of diet DM for CON, TPH20, and TPH14, respectively (Table 1). As described in the methods, TPH14 was discontinued midway through period 2 because of high prevalence of diarrhea and gastrointestinal tract abnormalities, common symptoms of clinical acidosis, which is often attributed to a lack of adequate peNDF in the diet (Blowey and Weaver, 2003). However, peNDF ${ }_{8.0}$ values for TPH20 and TPH14 were very similar, suggesting that this metric was not a good predictor of effectiveness of fiber for these diets.

Table 4 shows particle size separation for the treatments. Particles >19 mm were 21.6, 14.8, and $13.3 \%$ of DM for CON, TPH20, and TPH14, respectively, but were not significantly different. The proportion of particles retained on the middle screen was greatest for CON and least for TPH20 (24.3 vs. $16.2 \%$; $P<$ $0.05)$. The proportion of particles retained on the lower sieve was greatest for TPH20 and least for CON $(P<$ 0.05). Guidelines for particle size distributions in TMR as proposed by Heinrichs and Kononoff (2002) are to target 2 to $8 \%$ of particles on the upper sieve, 30 to $50 \%$ on the middle sieve, 30 to $50 \%$ on the lower sieve, and $\leq 20 \%$ in the pan. These targets were not met by any of the dietary treatments, but CON most closely resembled the recommended distribution. Interestingly, the proportion of particles $>19 \mathrm{~mm}$ greatly exceeded that of the guidelines, even for TPH14.

\section{DMI and Performance}

No evidence for any difference in DMI was apparent between treatments $(P=0.24$; Table 5$)$. This obser- 
Table 4. Particle size distribution (\% of DM)

\begin{tabular}{lccc}
\hline & \multicolumn{3}{c}{ Treatment $^{1}$} \\
\cline { 2 - 4 } $\begin{array}{l}\text { DM retained } \\
\text { on sieves, } \%\end{array}$ & CON & TPH20 & TPH14 \\
\hline $19.0 \mathrm{~mm}$ & $21.6 \pm 4.9$ & $14.8 \pm 4.7$ & $13.3 \pm 7.1$ \\
$8.0 \mathrm{~mm}$ & $24.3^{\mathrm{a}} \pm 2.9$ & $16.2^{\mathrm{b}} \pm 2.8$ & $17.5^{\mathrm{ab}} \pm 3.8$ \\
$1.18 \mathrm{~mm}$ & $46.7^{\mathrm{b}} \pm 6.9$ & $61.5^{\mathrm{a}} \pm 6.4$ & $64.1^{\mathrm{ab}} \pm 10.3$ \\
Pan & $7.6 \pm 0.7$ & $7.6 \pm 0.7$ & $7.8 \pm 1.1$ \\
\hline a,b Means within a row with different superscripts differ by Tukey's honestly significant difference test $(P<$ \\
$0.05)$.
\end{tabular}

vation was consistent with Schroeder (2003), who observed no change in DMI when WCGF was increased in the diet. Dry matter intake is controlled by a complex set of factors, and mechanisms that limit DMI may differ based on the nature of the diet being consumed. Dry matter intake of diets with greater amounts of peNDF is more likely to be limited by physical regulation mechanisms (Allen, 2000). However, in the case of TPH20 and TPH14, where peNDF ${ }_{8.0}$ was lower, a significant increase in intake was not observed. This may be explained by the differences in retention time of the forage included in the diet. Allen (2000) suggests that, compared with perennial grasses such as those found in tallgrass prairie, alfalfa particles possess a much higher fragility and a shorter buoyancy period, both of which would decrease retention time and therefore distention and satiety.

Milk yield was not significantly altered by treatment $(P=0.25$; Table 5$)$. Milk fat yield was greater for CON than for TPH14 and TPH20 (Table 6). Likewise, milk fat concentration was greatest for $\mathrm{CON}$ and least for TPH14 $(P<0.05)$; however, TPH20 milk fat concentration was not significantly different from CON. The decrease in milk fat yield for TPH20 was driven by a combination of small, nonsignificant decreases in both milk yield and fat content. Consistent with treatment effects on milk fat yield, ECM yield was lower for TPH20 and TPH14 than for CON $(P<0.05$; Table 5$)$. Although diets were formulated to be isocaloric, inclusion of prairie hay in TPH20 and TPH14 decreased the energy content by $\approx 50 \mathrm{kcal} / \mathrm{kg}$ of DM compared with CON (Table 1). To assess whether ECM responses were driven by differences in energy intake, milk energy output per unit of $\mathrm{NE}_{\mathrm{L}}$ intake was determined. As shown in Table 5, the efficiency of energy use for milk production was not significantly altered by treatment $(P=0.27)$. The almost identical efficiencies for $\mathrm{CON}$ and TPH20, in particular, suggest that ECM yield differences between these diets were likely a product of differences in dietary energy density. Likewise, no treatment effects on production efficiency (quantified as ECM/DMI) were detected $(P=0.14)$.

Diets containing as little as $9.6 \%$ peNDF $_{8.0}$ have maintained milk component yield and concentration equivalent to that of a diet containing $12.7 \%$ peNDF $_{8.0}$ (Yang and Beauchemin, 2007). In contrast, the TPH14 diet failed to maintain milk fat concentration with a peNDF $_{8.0}$ content of $10.7 \%$. A recent meta-analysis suggested the peNDF ${ }_{1.18}$ was a better predictor of ruminal $\mathrm{pH}$ and NDF digestibility than peNDF 8.0 (Zebeli et al., 2008). Although this may be true for traditional dairy rations, this metric would have been of little use in the

Table 5. Effects of treatments on DMI and performance

\begin{tabular}{|c|c|c|c|c|}
\hline \multirow[b]{2}{*}{ Item } & \multicolumn{3}{|c|}{ Treatment $^{1}$} & \multirow[b]{2}{*}{$P$-value } \\
\hline & $\mathrm{CON}$ & TPH20 & TPH14 & \\
\hline No. of observations ${ }^{2}$ & 53 & 53 & 15 & \\
\hline DMI, $\mathrm{kg} / \mathrm{d}$ & $24.9 \pm 0.86$ & $24.8 \pm 0.86$ & $27.1 \pm 1.32$ & 0.24 \\
\hline Milk yield, kg/d & $36.0 \pm 1.1$ & $34.6 \pm 1.1$ & $35.2 \pm 1.4$ & 0.25 \\
\hline ECM yield, $\mathrm{kg} / \mathrm{d}$ & $36.3 \pm 0.71^{\mathrm{a}}$ & $34.7 \pm 0.71^{\mathrm{b}}$ & $33.5 \pm 1.26^{\mathrm{b}}$ & 0.04 \\
\hline ECM/DMI & $1.47 \pm 0.06$ & $1.42 \pm 0.06$ & $1.24 \pm 0.10$ & 0.14 \\
\hline Milk energy $/ \mathrm{NE}_{\mathrm{L}}$ intake $^{3}$ & $0.628 \pm 0.026$ & $0.626 \pm 0.026$ & $0.554 \pm 0.043$ & 0.27 \\
\hline BW change, $\mathrm{kg} / 21 \mathrm{~d}$ & $7.2 \pm 3.8$ & $13.4 \pm 4.3$ & $6.0 \pm 5.0$ & 0.71 \\
\hline
\end{tabular}


Table 6. Effects of treatments on milk component yield and concentration

\begin{tabular}{|c|c|c|c|c|}
\hline \multirow[b]{2}{*}{ Item } & \multicolumn{3}{|c|}{ Treatment $^{1}$} & \multirow[b]{2}{*}{$P$-value } \\
\hline & $\mathrm{CON}$ & ТРH20 & TPH14 & \\
\hline Milk fat, $\mathrm{kg} / \mathrm{d}$ & $1.23 \pm 0.04^{\mathrm{a}}$ & $1.16 \pm 0.04^{\mathrm{b}}$ & $1.03 \pm 0.06^{\mathrm{b}}$ & 0.02 \\
\hline Milk fat, $\%$ & $3.48 \pm 0.14^{\mathrm{a}}$ & $3.41 \pm 0.14^{\mathrm{a}}$ & $2.82 \pm 0.21^{\mathrm{b}}$ & 0.02 \\
\hline Milk protein, $\mathrm{kg} / \mathrm{d}$ & $1.22 \pm 0.02^{\mathrm{a}}$ & $1.16 \pm 0.02^{\mathrm{b}}$ & $1.24 \pm 0.04^{\mathrm{ab}}$ & 0.03 \\
\hline Milk protein, $\%$ & $3.38 \pm 0.05$ & $3.38 \pm 0.05$ & $3.42 \pm 0.07$ & 0.69 \\
\hline Milk lactose, $\mathrm{kg} / \mathrm{d}$ & $1.73 \pm 0.05$ & $1.68 \pm 0.05$ & $1.74 \pm 0.08$ & 0.25 \\
\hline Milk lactose, \% & $4.87 \pm 0.02$ & $4.86 \pm 0.02$ & $4.89 \pm 0.04$ & 0.78 \\
\hline $\mathrm{SCC}, 10^{3}$ cells $/ \mathrm{mL}$ & $260 \pm 74$ & $195 \pm 74$ & $218 \pm 155$ & 0.72 \\
\hline MUN, mg/dL & $13.8 \pm 0.83^{\mathrm{b}}$ & $17.0 \pm 0.83^{\mathrm{a}}$ & $17.2 \pm 1.10^{\mathrm{a}}$ & $<0.01$ \\
\hline
\end{tabular}

current experiment; all 3 diets had approximately $92 \%$ of particles $>1.18 \mathrm{~mm}$ in length. In fact, because dietary NDF content increased in the TPH20 and TPH14 diets, peNDF $_{1.18}$ increased in these diets even as milk fat depression occurred in cows fed TPH14.

These observations support the definitions of peNDF and eNDF as proposed by Mertens (1997); not all eNDF is peNDF. Effective NDF relates to the ability of a feed to replace forage or roughage in a diet so that the concentration of fat in milk produced by cows eating the ration is maintained, whereas peNDF relates solely to the ability of the fiber to stimulate chewing and influence the consistency of the ruminal mat. By this definition, eNDF of CON and TPH20 did not differ because milk fat concentration did not differ significantly, and differences in fat yield were driven by the difference in milk yield. In contrast, the effectiveness of NDF was clearly lower for TPH14 based on the observed milk fat depression, despite the minimal differences in calculated peNDF for TPH20 and TPH14. The differences in eNDF and peNDF in these diets may be explained by the increased amount of WCGF in the TPH14 diet and its attributes as a highly digestible fiber source that promotes a moderate fermentation rate but provides little physical effectiveness to the diet because of its small particle size (Allen and Grant, 2000). The ability of the TPH20 diet to maintain acceptable milk fat production may also be related to its low starch content. Independent of effects on $\mathrm{pH}$, starch substrate was shown to promote the alternative biohydrogenation pathway (Maia et al., 2009) that leads to the absorption of milk-fat-depressing fatty acid isomers (Peterson et al., 2003).

Although milk fat response is perhaps the most unequivocal approach to measure the effectiveness of fiber in production settings, it is a post hoc method of determination and thus is not feasible for evaluating novel diet formulations without the loss of revenue resulting from milk fat depression. A more real-time method for predicting dietary effects on milk fat content may be the use of formulas that include particle size distributions as well as NDF concentrations of diets. Given that peNDF 8.0 and peNDF 1.18 had little predictive value in this study, physically effective NDF was alternately calculated using only forage NDF ( $\mathbf{p e F N D F} \mathbf{~}_{\mathbf{8 . 0}}$ ) values in an attempt to uncover a greater disparity between the diets and to account for the limited physical effectiveness of nonforage fiber (Table 1). If peFNDF ${ }_{8.0}$ is a useful measure, the breakpoint for decreased rumen function would lie somewhere between the peF$\mathrm{NDF}_{8.0}$ values for the diets: 3.9 and $1.0 \%$ for TPH20 and TPH14, respectively. However, it is unlikely that any single measure of diet characteristics would consistently predict rumen function and milk fat responses without including an estimate of fiber digestibility. For example, milk fat content was dramatically decreased when brown midrib corn silage replaced conventional corn silage, despite the fact that particle sizes and NDF concentrations were very similar across diets (Holt et al., 2010).

We found no evidence for any effect of treatment on milk lactose concentrations $(P=0.78)$. Likewise, no significant differences in protein concentration were observed among the 3 treatments $(P=0.69)$. However, TPH20 decreased milk protein yield compared with CON $(P<0.05$, Table 6$)$, again driven in part by the numerical decrease in milk yield for this treatment. Diets were formulated to be isocaloric and isonitrogenous; however, $\mathrm{CP}$ concentrations fluctuated between diets because of deviations in $\mathrm{CP}$ concentration of the respective grain mixes (Table 1). Milk urea nitrogen was greater for cows that consumed TPH20 and TPH14 than for those fed CON $(P<0.01$, Table 6$)$. Not surprisingly, these differences coincided with the differences in dietary CP; however, minimum target values for MUN of $10 \mathrm{mg} / \mathrm{dL}$ (Jonker et al., 1999) were met, suggesting that dietary protein was not likely a primary limitation for milk production in this study. The MUN concentrations observed for TPH20 and TPH14 also suggested that $\mathrm{CP}$ concentrations exceeding $18 \%$ of DM provided 
substantially more protein than required by the latelactation cows used in this experiment (Jonker et al., 1999).

Only a few published studies have evaluated responses of lactating dairy cattle to diets containing more than 50\% corn gluten feed (Ohajuruka and Palmquist, 1989; Fellner and Belyea, 1991). Boddugari et al. (2001) tested 3 different strategies for incorporating a modified WCGF product, pushing inclusion rates as high as $70 \%$ of DM. The approach of these investigators was different from that of the present study; the modified WCGF was used to replace all dietary concentrate, and the most extreme diet still contained $15 \%$ corn silage and $15 \%$ alfalfa, resulting in a diet with $41 \% \mathrm{NDF}$ and only 27\% NFC (Boddugari et al., 2001). Perhaps not surprisingly, this formulation strategy was more successful at preventing MFD than the TPH14 diet. Nevertheless, our goal was to address a scenario when supplies of traditional forages run low on a dairy farm, and alternative approaches to formulation are required. In such a circumstance, the TPH20 diet appears to be a viable option, in spite of the mild decrease in ECM yield caused by this treatment.

\section{CONCLUSIONS}

Although TPH14 apparently did not supply adequate physically effective fiber to maintain rumen health, TPH20 may be a feasible option for lactating dairy cows because it resulted in production efficiencies and milk fat concentrations that were not significantly different from that of CON. Use of a diet similar to TPH20 may sometimes be economically feasible in locations where WCGF and TPH are readily available, such as the US central plains region, where numbers of dairy cows are increasing. Determining the risk threshold for disrupted rumen function remains difficult, but ideally, metrics to predict rumen function should include estimates of fiber digestibility and dietary starch content in addition to particle size and NDF content of a diet.

\section{ACKNOWLEDGMENTS}

Contribution no. 11-384-J from the Kansas Agricultural Experiment Station. The authors thank Mike Scheffel and Terry Gugle (Kansas State University, Manhattan) for assisting with this study as well as Cargill Corn Milling (Blair, NE) for partially funding this research.

\section{REFERENCES}

Allen, D. M., and R. J. Grant. 2000. Interactions between forage and wet corn gluten feed as sources of fiber in diets for lactating dairy cows. J. Dairy Sci. 83:322-331.
Allen, M. S. 2000. Effects of diet on short-term regulation of feed intake by lactating dairy cattle. J. Dairy Sci. 83:1598-1624.

AOAC. 2000. Official Methods of Analysis. 17th ed. Association of Official Analytical Chemists, Arlington, VA.

Blowey, R. W., and A. D. Weaver. 2003. Color Atlas of Diseases and Disorders of Cattle. 2nd ed. Elsevier Science Ltd., Amsterdam, the Netherlands.

Boddugari, K., R. J. Grant, R. Stock, and M. Lewis. 2001. Maximal replacement of forage and concentrate with a new wet corn milling product for lactating dairy cows. J. Dairy Sci. 84:873-884.

Fellner, V., and R. L. Belyea. 1991. Maximizing gluten feed in corn silage diets for dairy cows. J. Dairy Sci. 74:996-1005.

Heinrichs, A. J., and P. J. Kononoff. 2002. Evaluating Particle Size of Forages and TMRs Using the New Penn State Forage Particle Separator. Pennsylvania State University Department of Dairy and Animal Science, State College.

Holt, M. S., C. M. Williams, C. M. Dschaak, J. S. Eun, and A. J. Young. 2010. Effects of corn silage hybrids and dietary nonforage fiber sources on feed intake, digestibility, ruminal fermentation, and productive performance of lactating Holstein dairy cows. J. Dairy Sci. 93:5397-5407.

Jonker, J. S., R. A. Kohn, and R. A. Erdman. 1999. Milk urea nitrogen target concentrations for lactating dairy cows fed according to national research council recommendations. J. Dairy Sci 82:1261-1273

Kononoff, P. J., A. J. Heinrichs, and D. R. Buckmaster. 2003. Modification of the Penn State forage and total mixed ration particle separator and the effects of moisture content on its measurements. J. Dairy Sci. 86:1858-1863.

Maia, M. R. G., R. J. B. Bessa, and R. J. Wallace. 2009. Is the trans-10 shift that sometimes occurs in the ruminal biohydrogenation of linoleic acid caused by low $\mathrm{pH}$ or starch? A Rusitec study. Pages 276-277 in Ruminant Physiology: Digestion, Metabolism, and Effects of Nutrition on Reproduction and Welfare. Y. Chilliard, F. Glasser, Y. Faulconnier, F. Bocquier, I. Veissier, and M. Doreau, ed. Wageningen Academic Publishers, Wageningen, the Netherlands.

Mertens, D. R. 1997. Creating a system for meeting the fiber requirements of dairy cows. J. Dairy Sci. 80:1463-1481.

Mowrey, A., and J. N. Spain. 1999. Results of a nationwide survey to determine feedstuffs fed to lactating dairy cows. J. Dairy Sci. $82: 445-451$.

Mullins, C. R., K. N. Grigsby, and B. J. Bradford. 2009. Effects of alfalfa hay inclusion rate on productivity of lactating dairy cattle fed wet corn gluten feed-based diets. J. Dairy Sci. 92:3510-3516.

NRC. 2001. Nutrient Requirements of Dairy Cattle. 7th rev. ed. National Research Council. Natl. Acad. Sci., Washington, DC.

Ohajuruka, O. A., and D. L. Palmquist. 1989. Response of high-producing dairy cows to high levels of dried corn gluten feed. Anim. Feed Sci. Technol. 24:191-200.

Olson, K. C., R. C. Cochran, E. C. Titgemeyer, C. P. Mathis, T. J. Jones, and J. S. Heldt. 2008. Prediction of the energy content of tallgrass prairie hay. J. Anim. Sci. 86:1372-1381.

Peterson, D. G., E. V. Matitashvil, and D. E. Bauman. 2003. Diet-induced milk fat depression in dairy cows results in increased trans-10, cis-12 CLA in milk fat and coordinate suppression of mRNA abundance for mammary enzymes involved in milk fat synthesis. J. Nutr. 133:3098-3102.

Schroeder, J. W. 2003. Optimizing the level of wet corn gluten feed in the diet of lactating dairy cows. J. Dairy Sci. 86:844-851.

Short, S. D. 2004. Characteristics and production costs of U.S. dairy operations. USDA Economic Research Service. Statistical Bulletin 974-6. USDA, Washington, DC.

Van Soest, P. J., J. B. Robertson, and B. A. Lewis. 1991. Methods for dietary fiber, neutral detergent fiber, and nonstarch polysaccharides in relation to animal nutrition. J. Dairy Sci. 74:3583-3597.

Wickersham, E. E., J. E. Shirley, E. C. Titgemeyer, M. J. Brouk, J. M. DeFrain, A. F. Park, D. E. Johnson, and R. T. Ethington. 2004. Response of lactating dairy cows to diets containing wet corn gluten feed or a raw soybean hull-corn steep liquor pellet. J. Dairy Sci. 87:3899-3911 
Yang, W. Z., and K. A. Beauchemin. 2007. Altering physically effective fiber intake through forage proportion and particle length: Chewing and ruminal pH. J. Dairy Sci. 90:2826-2838.

Yang, W. Z., and K. A. Beauchemin. 2009. Increasing physically effective fiber content of dairy cow diets through forage proportion versus forage chop length: Chewing and ruminal pH. J. Dairy Sci. 92:1603-1615.
Zebeli, Q., J. Dijkstra, M. Tafaj, H. Steingass, B. N. Ametaj, and W. Drochner. 2008. Modeling the adequacy of dietary fiber in dairy cows based on the responses of ruminal $\mathrm{pH}$ and milk fat production to composition of the diet. J. Dairy Sci. 91:2046-2066. 